\title{
Effect of feeding rabbits on fungal treated corn stalks on carcass characteristics and meat composition
}

\author{
Roshdy I. El-Kady, Ashraf A. A. Morad, Abdelmegid A. Abedo* and Ali A. El-Shahat
}

\begin{abstract}
Background: Corn stalk as low quality roughage is high in lignocellulytic materials and low in readily available carbohydrates and nitrogen as well as several minerals. Intake and utilization of it can be increase by applying some treatments; physical, chemical, and biological methods, biological method shows the most effective method. This study aimed to evaluate the effect of replacing clover hay (it is high quality roughage in Egypt and high price) by fungal treated corn stalks with Trichoderma ressei on carcass characteristics and meat analysis of rabbits. Forty-two weaned New Zealand white rabbits were divided to two groups. The first group (24 rabbits) was divided into 4 subgroups (6 each), and were fed diets contained 0\% corn stalks (control), 33, 66, and 100\% treated corn stalks with media only (without Trichoderma ressei). The second group (18 rabbits) was divided into 3 subgroups (6 each), and were fed diets contained 33, 66, and 100\% fungal treated corn stalks with Trichoderma ressei as replaced of clover hay $(11,22$, and $33 \%$ of whole), each group was divided into 3 replicates (2 each). At the end of the trial, 3 rabbits from each group were slaughtered to derermine carcass characteristics and chemical composition of meat.

Results: There were no significant differences in values of dressing percentages either between treatments or levels. Also, the interaction between treatments and levels were no significant. Feeding fungal treated corn stalks did not significant effect on dry matter (DM), crude protein (CP), and ether extract (EE), while significant $(P<0.05)$ increased ash content compared with without Trichoderma reesei. And feeding 100\% corn stalks recorded $(P<0.05)$ the highest value compared with levels 33 and $66 \%$. The interaction between treatments and levels on $\mathrm{CP}$, EE, and ash was significant, the results pointed that fed level of $66 \%$ treated corn stalks was significant $(P<0.05)$ increased CP content compared with 66\% without Trichoderma reesei. Also fed level of 100\% treated corn stalks was recorded $(P<0.05)$ the highest value of ash content compared with level of $66 \%$ treated CS and with levels of 33, 66, and $100 \%$ without Trichoderma reesei, respectively. While fed treated corn stalks at $66 \%$ significant $(P<0.05)$ decreased EE content compared with feeding level of $66 \%$ without Trichoderma reesei. But, there were no significant difference in DM content. It could be concluded that treated corn stalks with fungi could be used without any adverse effects and enhance carcass characteristics and chemical composition of rabbits meat.
\end{abstract}

Keywords: Fungal treatment, Carcass characteristics, Meat composition, Rabbits

\footnotetext{
* Correspondence: abedoaa@yahoo.com

Animal Production Department, National Research Centre, 33 El Bohouth St., Dokki, Giza P.O. 12622, Egypt
} 


\section{Background}

In Egypt the farm animals suffer from shortage of feeds and, also, are continuously increasing in prices. However, annually many million tons of agricultural by-products are producing from fields and processing of vegetables and fruits. Annually, in Egypt about 25 million tons from agricultural by-products produced (MALR 2008). The nutritive value of agricultural by-products can be enhanced through their biological treatments. It was estimates that about 13.0 million tons of total digestible nutrients (TDN) are required per year in Egypt, while only 9.6 million tons are annually produced providing $75 \%$ of livestock energy requirements (AESI 2011).

Corn stalk as low quality roughage is high in lignocellulytic materials and low in readily available carbohydrates and nitrogen as well as several minerals. Also, its utilization is limited as a result of low feed intake by the animals and high transportation cost, being bulky (Rissanen et al. 1981 and Abedo 2011).

A great deal of research was carried out to increase use of this by-products and increasing its feeding value. Intake and utilization of such roughages can be increase by supplementation with some nutrients or by applying some treatments; physical, chemical, and biological methods (Rangnekar et al. 1982 and Cheeke 1987). Biological method shows the most effective method among the different methods (Deraz and Ismail 2001; Morad 2005 and Abd El-Hakim et al. 2006 and Abedo 2011).

Morad (2005) and Abd El-Hakim et al. (2006) stated that feeding biological treated corn stalks and rice straw did not significant effect on dressing percentage of rabbits, while El-Badawi et al. (2007) reported that feeding biological treated sugar beet pulp significant increased dressing percentage for rabbits.

Morad (2005), Abd El-Hakim et al. (2006), and El-Badawi et al. (2007) reported that chemical composition of rabbits meat was significant affected by feeding biological treated rice straw and sugar beet pulp. Hernandez et al. (2000) mentioned that rabbit can be contribute to solve the meat shortage in developing countries, because rabbits have rapid growth rate, high fertility, short gestation period, short generation intervals, high feed efficiency, early marketing age, high muscle bone ratio, also, its meat has high protein, low fat and cholesterol contents.

This study aimed to study effect of replacing clover hay (it is high quality roughage in Egypt and high price) by fungal treated corn stalks with Trichoderma ressei on carcass characteristics and meat composition for growing rabbits.

\section{Materials and methods Microorganisms}

Trichoderma ressei was obtained from Agriculture Microbiology Department, National Research Centre, Dokki, Giza, Egypt.

\section{Mycotoxin determination}

Thin layer chromatography for determination of mycotoxin of treated material was applied according to the method described by AOAC (2000) and Fadel et al. (1992).

\section{Fungal treatment}

Three-day old slants cultures of Trichoderma ressei was crushed into conical flasks containing $20 \mathrm{ml}$ sterilized water, the fungal spores suspension used as inoculant at $10 \% \mathrm{~V} / \mathrm{W}$ to inoculate $25 \mathrm{~g}$ ground corn stalks moistened at 1:2 solid: liquid ratio in $500 \mathrm{ml}$ capacity conical flasks with medium consists of $0.2 \%$ urea, $0.02 \%$ potassium di-hydrogen phosphate, $0.03 \%$ magnesium sulfate, and $4.0 \%$ sugarcane molasses, the inoculated flasks were incubated for $72 \mathrm{~h}$. at $30^{\circ} \mathrm{C}$. The previous inoculate used to inoculate $500 \mathrm{~g}$ moistened corn stalks with the previous medium at 1 solid: 2 liquid at $10 \% \mathrm{~V} / \mathrm{W}$ then packed in $50 \times 100 \mathrm{~cm}$ polyethylene bags. The inoculated bags were incubated for 10 days at room temperature $\left(30 \pm 2^{\circ}\right.$ C) according to Fadel et al. (1992).

One hundred and sixty kg chopped corn stalks equally divided to two heaps. The first heap moistened at 1 solid: 2 liquid with medium consists of (\%); 1.5 ammonium sulphate, 2.5 urea, 1.0 supper phosphate, 0.5 magnesium sulphate, and 2.5 molasses, mixed well and then spread on plastic sheet without Trichoderma reesei. The second heap moistened with the same medium and inoculated with the above prepared inoculant of Trichoderma reesei at $10 \%$, mixed well, then spread on plastic sheet. The two heaps shuffled upside down daily for 2 weeks (the proper fermentation period). At the end of fermentation period, the treated corn stalks was exposed to sun dry until its moisture reached to less than $10 \%$, then packed and stored until use it to manufacturing the experimental pelleted diets.

\section{Experimental diets}

Dried treated corn stalks without and with Trichoderma reesei were used to formulate the experimental diets by replacing clover hay at $0,33,66$ and $100 \%(0,11,22$, and $33 \%$ of whole diet, respectively). 7 diets were formulated to be iso-caloric and iso-nitrogenous and to cover the nutrients requirements for growing rabbits according to NRC (1977) recommendation as presented in Table 1.

\section{Animals and feeding trials}

Forty-two weaned New-Zealand white rabbits, weighted $500 \mathrm{~g} \pm 90 \mathrm{~g}$ and aged 6 weeks were randomly divided into two groups. The first group (24 rabbits) was divided into 4 subgroups ( 6 each), and were fed diets contained $0 \%$ corn stalks (control), 33, 66, and 100\% treated corn stalks with media only (without Trichoderma ressei). The second group (18 rabbits) was divided into 3 subgroups (6 each), 
Table 1 Formulation of the experimental diets

\begin{tabular}{|c|c|c|c|c|c|c|c|}
\hline \multirow[t]{3}{*}{ Component } & \multirow[t]{3}{*}{$0 \%$ (Control) } & \multicolumn{6}{|l|}{ Diets } \\
\hline & & \multicolumn{3}{|c|}{ Without T. ressei } & \multicolumn{3}{|c|}{ With T. ressei } \\
\hline & & $33 \%$ & $66 \%$ & $100 \%$ & $33 \%$ & $66 \%$ & $100 \%$ \\
\hline Barley & 14.46 & 2.00 & 1.50 & 1.50 & 2.00 & 1.50 & 1.50 \\
\hline Yellow corn & 15.75 & 31.00 & 39.35 & 38.75 & 31.00 & 39.35 & 38.75 \\
\hline Wheat bran & 16.50 & 11.00 & 0.60 & 0.60 & 11.00 & 4.25 & 5.25 \\
\hline Soybean meal & 17.40 & 19.65 & 21.65 & 21.65 & 19.65 & 18.00 & 17.0 \\
\hline Clovr hay & 33.00 & 22.00 & 11.00 & - & 22.00 & 11.00 & - \\
\hline Corn stalks & - & 11.00 & 22.00 & 33.00 & 11.00 & 22.00 & 33.00 \\
\hline $\mathrm{NaCl}$ & 0.40 & 0.40 & 0.40 & 0.40 & 0.40 & 0.40 & 0.40 \\
\hline Calcium Di-phosphate & 2.05 & 2.40 & 2.85 & 3.05 & 2.40 & 2.85 & 3.05 \\
\hline Lime stone & 0.10 & 0.20 & 0.25 & 0.60 & 0.20 & 0.25 & 0.60 \\
\hline Premix * & 0.30 & 0.30 & 0.30 & 0.30 & 0.30 & 0.30 & 0.30 \\
\hline L.Meth. & 0.04 & 0.05 & 0.10 & 0.15 & 0.05 & 0.10 & 0.15 \\
\hline \multicolumn{8}{|l|}{ Calculated ${ }^{* *}$} \\
\hline Digestible energy, K cal/Kg & 2513 & 2503 & 2495 & 2412 & 2518 & 2501 & 2425 \\
\hline $\mathrm{Ca}$ & 1.08 & 1.04 & 1.01 & 1.03 & 0.970 & 0.92 & 0.96 \\
\hline$P$ & 0.80 & 0.80 & 0.79 & 0.80 & 0.82 & 0.79 & 0.83 \\
\hline $\mathrm{Na}$ & 0.20 & 0.19 & 0.18 & 0.17 & 0.17 & 0.18 & 0.17 \\
\hline Lysine & 0.89 & 0.85 & 0.80 & 0.74 & 0.85 & 0.71 & 0.63 \\
\hline Methionine & 0.55 & 0.57 & 0.57 & 0.58 & 0.56 & 0.46 & 0.54 \\
\hline
\end{tabular}

*Each kg contains; $2000 \mathrm{IU}$ Vit. A, $0.33 \mathrm{~g}$ Vit. $\mathrm{B}_{1}, 1.09$ Vit $\mathrm{B}_{2}, 150 \mathrm{IU}$ Vit $\mathrm{B}_{3}, 8.33 \mathrm{~g}$ Vit E, $0.33 \mathrm{~g}$ Vit K, $3.33 \mathrm{~g}$ pantothemic acid, $30 \mathrm{~g}$ nicatonic acid, $2 \mathrm{~g}$ Vit $\mathrm{B}_{6}, 1.7 \mathrm{mg}$ Vit $\mathrm{B}_{12}, 0.039$ folic acid, $33 \mathrm{mg}$ biotin. $0.50 \mathrm{~g} \mathrm{Cu}, 200 \mathrm{mg}$ cholin chloride, $5.0 \mathrm{~g} \mathrm{Mn}, 12.5 \mathrm{~g} \mathrm{Fe}, 66.7 \mathrm{mg} \mathrm{Mg}, 1.33 \mathrm{mg} \mathrm{Co}, 16.6 \mathrm{mg} \mathrm{Se}, 11.9 \mathrm{Zn}, 16.6 \mathrm{mg}$ lodine, and $10.0 \mathrm{~g}$ Antioxidant

**according to Cheeke (1987) using the following equation: $\mathrm{DE}=4.36-0.0491 \times \mathrm{NDF} \%$

and were fed diets contained 33,66 , and $100 \%$ fungal treated corn stalks with Trichoderma ressei as replaced of clover hay $(11,22$, and $33 \%$ of whole), each group was divided into 3 replicates ( 2 each). The experimental animals groups were fed the pervious experimental diets for 91 days. All animals were housed in metal battery cages (2 rabbits each) and kept under the same managerial and hygienic conditions.

\section{Slaughter trials}

At the end of feeding trial, animals were fasted for $12 \mathrm{~h}$. Before sacrificing rabbits were individually weighted, and 3 rabbits from each group were randomly chosen, slaughtered by cutting the neck and jugular vein using sharp knife to determine carcass characteristics and meat analysis. The slaughtered weight was recorded after complete bleeding, then shinning off was done. The skin, viscera, lung, heart, liver, and kidneys were removed, then rest of the rabbit body was weighted to valuate the dressing percentage. Carcass cuts included fore part, middle part, hind part and head with neck were weighted. The cracass meat samples were taken from 9, 10 and 11 th ribs, dried for $24 \mathrm{~h}$. at $60^{\circ} \mathrm{C}$, and kept to determine the chemical composition.

\section{Analytical methods}

Colleced samples of the carcass meat was analyzed for determine dry matter $(\mathrm{DM})$, crude protein $(\mathrm{CP})$, ether extract (EE), and ash according to AOAC (2000).

\section{Statistical analysis}

Collected data of experiment were subjected to statistical analysis as two factors-factorial analysis of variance using SPSS (1997). And Duncan's multiple range test was used for separate means when the differences were significant according to Duncan (1955). And the statistical model was $Y_{i j k}=\mu+T i+L_{j}+(T L)_{i j}+e_{i j k}$.

Where; $\mathrm{Y}_{\mathrm{ijk}}$ : The observation, $\mu$ : mean, Ti: Treatment effect, $\mathrm{L}_{\mathrm{j}}$ : Level effect, $\mathrm{TL}_{\mathrm{ij}}$ : Interaction effect between treatments and levels, and $\mathrm{e}_{\mathrm{ijk}}$ : Experimental error.

\section{Results}

\section{Carcass characteristics}

Values of slaughter weights (SW), empty body weight (EBW), carcass weight $\left(\mathrm{CW}_{1}\right)$, carcass weight + total edible offals $\left(\mathrm{CW}_{2}\right)$, edible offals (giblets), dressing percentages and carcass cuts are show in Table 2. And the interaction between treatments and levels show in Table 3. The results indicated that there were no significant differences in values of $\mathrm{EBW}, \mathrm{CW}_{1}, \mathrm{CW}_{2}$ and dressing percentages $(1,2$, 
Table 2 Effects of fungal treatments and replacing levels of corn stalks on carcass characteristics for growing rabbits

\begin{tabular}{|c|c|c|c|c|c|c|c|c|}
\hline \multirow[t]{2}{*}{ Item } & \multicolumn{2}{|l|}{ Treatments } & \multirow[t]{2}{*}{ SEM } & \multicolumn{4}{|l|}{ Levels } & \multirow[t]{2}{*}{ SEM } \\
\hline & Without $T$. reesei & With T. reesei & & $0 \%$ & $33 \%$ & $66 \%$ & $100 \%$ & \\
\hline Initial body wt., g* & 571 & 553 & 20.73 & 566 & 572 & 568 & 542 & 20.71 \\
\hline Final body wt., $\mathrm{g}^{*}$ & $2060^{b}$ & $2254^{a}$ & 32.99 & $2079^{b c}$ & $2361^{a}$ & $2199^{b}$ & $1990^{c}$ & 32.99 \\
\hline Daily gain, g/day* & $16.36^{b}$ & $18.69^{\mathrm{a}}$ & 0.30 & $16.63^{c}$ & $19.66^{\mathrm{a}}$ & $17.92^{b}$ & $15.91^{d}$ & 0.30 \\
\hline Slaughter wt. (SW), g & 2321 & 2505 & 75.05 & 2348 & 2426 & 2348 & 2529 & 75.05 \\
\hline Empty body wt. (EBW), g & 2098 & 2263 & 67.80 & 2122 & 2192 & 2122 & 2286 & 67.80 \\
\hline Carcass wt. $\left(\mathrm{CW}_{1}\right), \mathrm{g}$ & 1262 & 1353 & 37.92 & 1257 & 1337 & 1268 & 1369 & 37.92 \\
\hline Carcass wt. + total giblets $\left(\mathrm{CW}_{2}\right), \mathrm{g}$ & 1379 & 1482 & 41.59 & 1358 & 1460 & 1401 & 1504 & 41.59 \\
\hline \multicolumn{9}{|l|}{ Dressing percentages (DP), \% } \\
\hline DP1 & 54.56 & 54.10 & 0.54 & 53.67 & 55.17 & 54.09 & 54.38 & 0.54 \\
\hline DP2 & 60.38 & 59.87 & 0.60 & 59.39 & 61.06 & 59.87 & 60.19 & 0.60 \\
\hline DP3 & 65.94 & 65.57 & 0.58 & 64.12 & 66.71 & 66.16 & 66.03 & 0.58 \\
\hline \multicolumn{9}{|l|}{ Carcass cuts weight, g } \\
\hline Fore part & 385 & 416 & 14.05 & 383 & 397 & 399 & 424 & 14.05 \\
\hline Middle part & 252 & 269 & 8.74 & $228^{b}$ & $279^{\mathrm{a}}$ & $250^{\mathrm{ab}}$ & $285^{a}$ & 8.74 \\
\hline Hind part & 458 & 499 & 15.78 & 477 & 486 & 460 & 490 & 15.78 \\
\hline Head + Neck & 168 & 168 & 4.24 & 168 & 175 & 158 & 169 & 4.24 \\
\hline \multicolumn{9}{|l|}{ Edible offals (giblets), g } \\
\hline Kidneys & 18.75 & 19.58 & 0.76 & 17.67 & 19.33 & 19.17 & 20.50 & 0.76 \\
\hline Liver & $73.50^{b}$ & $85.17^{a}$ & 4.14 & $61.00^{b}$ & $78.00^{\mathrm{ab}}$ & $92.33^{a}$ & $86.00^{\mathrm{a}}$ & 4.14 \\
\hline Heart & 8.83 & 9.08 & 0.66 & 7.00 & 8.83 & 9.00 & 11.00 & 0.66 \\
\hline Lungs & 15.00 & 14.17 & 0.91 & 14.00 & 16.50 & 12.17 & 15.67 & 0.91 \\
\hline spleen & 1.00 & 1.00 & 0.00 & 1.00 & 1.00 & 1.00 & 1.00 & 0.00 \\
\hline Total & 117.1 & 129.0 & 5.43 & $100.7^{b}$ & $123.7^{\mathrm{ab}}$ & $133.7^{\mathrm{a}}$ & $134.2^{\mathrm{a}}$ & 5.43 \\
\hline
\end{tabular}

$\mathrm{a}$ and $\mathrm{b}$ : Means in the same row have different superscripts are differ significantly at $p<0.05 . \mathrm{SEM}$ : Standard error of the mean. $\mathrm{Dp} \mathrm{p}_{1}=\mathrm{CW}_{1} / \mathrm{SW}_{\mathrm{B}} \mathrm{DP}_{2}=\mathrm{CW}_{1} / \mathrm{EBW}$ $\mathrm{DP}_{3}=\mathrm{CW}_{2} /$ EBW. *: El-Ayek et al. 2014

and 3) either between treatments or levels as show in Table 2. Also, the interaction between treatments and levels were no significant (Table 3). The treatments were not significant effect on carcass cuts (fore part, middle part, and hind part), while level of 66 and 100\% corn stalks were significantly $(P<0.05)$ recorded higher middle part compared with control (Table 2). The interaction between treatments and levels on carcass cuts were no significant (Table 3). The results showed that feeding fungal treated corn stalks significant increased liver weight compared with without Trichoderma ressei and feeding levels of 66 and 100\% $(P<0.05)$ increased liver weight and total edible offals compared with control (Table 2). The interaction show that feeding treated corn stalks at levels 66 and 100\% $(P<0.05)$ increased liver weight compared with control as show in Table 3.

\section{Meat composition}

Table 4 shows the effect of treatments and levels on meat composition. The results indicated that fed fungal treated corn stalks did not significant effect on dry matter (DM), crude protein $(\mathrm{CP})$, and ether extract $(\mathrm{EE})$, while significant $(P<0.05)$ increased ash content $(2.64)$ compared with $2.17 \%$ for without Trichoderma reesei and feeding level of $100 \%$ corn stalks recorded $(P<0.05)$ the highest value compared with levels 33 and $66 \%$. Effect of interaction between treatments and replacing levels show in Table 5, the results pointed that fed level of $66 \%$ treated corn stalks was significant $(P<0.05)$ increased $\mathrm{CP}$ content compared with 66\% without Trichoderma reesei. Also fed level of 100\% treated corn stalks was recorded $(\mathrm{P}<0.05)$ the highest value of ash content (3.02) compared with $2.37 \%$ for level of $66 \%$ treated CS and 1.92, 1.94, and 2.18\% for levels of 33, 66, and $100 \%$ without Trichoderma reesei, respectively. While fed treated corn stalks at $66 \%$ significant $(\mathrm{P}<0.05)$ decreased EE content (32.04) compared with 39.16\% with feeding level of $66 \%$ without Trichoderma reesei. But, there were no significant difference in DM content.

\section{Discussion}

\section{Carcass characteristics}

Results concerning carcass characteristics are shown in Table 2, it was evident that treated corn stalks with fungi 
Table 3 Effect of interaction between fungal treatments and replacing levels of corn stalks on carcass characteristics for growing rabbits

\begin{tabular}{|c|c|c|c|c|c|c|c|c|}
\hline \multirow[t]{3}{*}{ Item } & \multirow[t]{3}{*}{$0 \%$} & \multicolumn{6}{|l|}{ Diets } & \multirow[t]{3}{*}{ SEM } \\
\hline & & \multicolumn{3}{|c|}{ Without T. reesei } & \multicolumn{3}{|c|}{ With $T$. reesei } & \\
\hline & & $33 \%$ & $66 \%$ & $100 \%$ & $33 \%$ & $66 \%$ & $100 \%$ & \\
\hline Initial body wt., $\mathrm{g}^{*}$ & 566 & 568 & 581 & 570 & 576 & 554 & 514 & 20.71 \\
\hline Final body wt., $g^{*}$ & $2079^{c}$ & $2207^{b c}$ & $2055^{\mathrm{cd}}$ & $1900^{d}$ & $2515^{a}$ & $2344^{\mathrm{ab}}$ & $2080^{c}$ & 32.99 \\
\hline Daily gain, g/day* & $16.63^{d}$ & $18.01^{c}$ & $16.19^{e}$ & $14.62^{f}$ & $21.31^{\mathrm{a}}$ & $19.67^{b}$ & $17.21^{d}$ & 0.30 \\
\hline Slaughter weight (SW), g & 2348 & 2302 & 2319 & 2316 & 2549 & 2377 & 2744 & 75.05 \\
\hline Empty body wt. (EBW), g & 2122 & 2080 & 2096 & 2092 & 2304 & 2147 & 2479 & 67.80 \\
\hline Carcass wt. $\left(\mathrm{CW}_{1}\right), \mathrm{g}$ & 1257 & 1279 & 1222 & 1290 & 1394 & 1313 & 1448 & 37.92 \\
\hline Carcass wt. + total giblets $\left(\mathrm{CW}_{2}\right), \mathrm{g}$ & 1358 & 1400 & 1344 & 1415 & 1521 & 1459 & 1592 & 41.59 \\
\hline \multicolumn{9}{|l|}{ Dressing percentages (DP), \% } \\
\hline DP1 & 53.67 & 55.63 & 52.91 & 56.03 & 54.71 & 55.27 & 52.73 & 0.54 \\
\hline DP2 & 59.39 & 61.57 & 58.56 & 62.01 & 60.55 & 61.18 & 58.36 & 0.60 \\
\hline DP3 & 64.12 & 67.37 & 64.37 & 67.90 & 66.05 & 67.95 & 64.15 & 0.58 \\
\hline \multicolumn{9}{|l|}{ Carcass cuts weight, $\mathrm{g}$} \\
\hline Fore part & 383 & 387 & 370 & 399 & 408 & 427 & 448 & 14.05 \\
\hline Middle part & 228 & 266 & 243 & 272 & 291 & 258 & 298 & 8.74 \\
\hline Hind part & 477 & 455 & 450 & 448 & 517 & 470 & 533 & 15.78 \\
\hline Head + Neck & 168 & 172 & 159 & 171 & 178 & 159 & 169 & 4.24 \\
\hline \multicolumn{9}{|l|}{ Edible offals (giblets), g } \\
\hline Kidneys & 17.67 & 20.33 & 17.33 & 19.67 & 18.33 & 21.00 & 21.33 & 0.76 \\
\hline Liver & $61.00^{\mathrm{b}}$ & $73.67^{\mathrm{ab}}$ & $82.67^{\mathrm{ab}}$ & $76.67^{a b}$ & $88.33^{\mathrm{ab}}$ & $102.00^{\mathrm{a}}$ & $95.33^{\mathrm{a}}$ & 4.14 \\
\hline Heart & 7.00 & 8.67 & 8.33 & 11.33 & 9.00 & 9.67 & 10.67 & 0.66 \\
\hline Lungs & 14.00 & 17.00 & 12.67 & 16.33 & 16.00 & 11.67 & 15.00 & 0.91 \\
\hline spleen & 1.00 & 1.00 & 1.00 & 1.00 & 1.00 & 1.00 & 1.00 & 0.00 \\
\hline Total & $100.7^{b}$ & $120.7^{\mathrm{ab}}$ & $122.0^{\mathrm{ab}}$ & $125.0^{\mathrm{ab}}$ & $126.7^{\mathrm{ab}}$ & $145.3^{\mathrm{a}}$ & $143.3^{\mathrm{a}}$ & 5.43 \\
\hline
\end{tabular}

$\mathrm{a}$ and $\mathrm{b}$ : Means in the same row have different superscripts are differ significantly at $P<0.05$. SEM: Standard error of the mean. $\mathrm{Dp}_{1}=\mathrm{CW}_{1} / \mathrm{SW}_{1} \mathrm{DP}_{2}=\mathrm{CW}_{1} / \mathrm{EBW}$ $\mathrm{DP}_{3}=\mathrm{CW}_{2} /$ EBW, *: El-Ayek et al. 2014

improved EBW, CW1 and CW2 by about 7.9, 7.2 and $7.5 \%$ for treated corn stalks with fungi than that of without fungi, respectively, however on significant differences were detected may be due to the variations within groups and the relatively small number of observation.

From data concerning dressing percentages (DP \%), DP1, DP2 and DP3 showed slight non-significant differences between treatments with and without fungi or between different levels of supplementation than un-supplemented diets.
These results are in agreement with Nofal et al. (1995) who showed that the dressing percentage of slaughter rabbits at 14-16 weeks of age was $60.6,60.1$, and $60.8 \%$ for New Zealand, California and California x New Zealand rabbits, respectively. Moreover, Ahmed (1998) observed that using $5 \%$ wheat straw which treated with fungi Trichoderma reesei in rabbit ration gave the highest value of dressing percentages (60.28), while rabbit given $15 \%$ wheat straw gave the lowest value (50.04\%). Also, El-Badawi et al. (2007)

Table 4 Effects of fungal treatments and replacing levels of corn stalks on chemical composition of rabbit meat

\begin{tabular}{|c|c|c|c|c|c|c|c|c|}
\hline \multirow[t]{2}{*}{ Component, \% } & \multicolumn{2}{|l|}{ Treatments } & \multirow[t]{2}{*}{ SEM } & \multicolumn{4}{|c|}{ Levels of corn stalks } & \multirow[t]{2}{*}{ SEM } \\
\hline & Without T. reesei & With $T$. reesei & & $0 \%$ & $33 \%$ & $66 \%$ & $100 \%$ & \\
\hline Dry matter (DM) & 39.31 & 39.41 & 0.99 & 35.92 & 40.08 & 40.90 & 40.54 & 0.99 \\
\hline Crude protein (CP) & 61.02 & 62.02 & 0.70 & 61.10 & 62.20 & 62.25 & 60.52 & 0.70 \\
\hline Ether extract (EE) & 36.81 & 35.34 & 0.67 & 36.24 & 35.58 & 35.60 & 36.88 & 0.67 \\
\hline Ash & $2.17^{\mathrm{b}}$ & $2.64^{\mathrm{a}}$ & 0.09 & $2.66^{\mathrm{a}}$ & $2.22^{\mathrm{b}}$ & $2.15^{b}$ & $2.60^{a}$ & 0.09 \\
\hline
\end{tabular}

$\mathrm{a}$ and $\mathrm{b}$ : Means in the same row have different superscripts are differ significantly at $P<0.05$ 
Table 5 Effect of interactions between treatments and levels of corn stalks on chemical composition of rabbit meat

\begin{tabular}{|c|c|c|c|c|c|c|c|c|}
\hline \multirow[t]{3}{*}{ Comp. } & \multirow[t]{3}{*}{$0 \%$} & \multicolumn{6}{|l|}{ Diets } & \multirow[t]{3}{*}{ SEM } \\
\hline & & \multicolumn{3}{|c|}{ Without $T$. reesei } & \multicolumn{3}{|c|}{ With T. reesei } & \\
\hline & & $33 \%$ & $66 \%$ & $100 \%$ & $33 \%$ & $66 \%$ & $100 \%$ & \\
\hline DM, \% & 35.92 & 40.31 & 41.00 & 40.02 & 39.85 & 40.80 & 41.06 & 0.99 \\
\hline$C P, \%$ & $61.10^{\mathrm{ab}}$ & $62.92^{\mathrm{ab}}$ & $58.90^{\mathrm{b}}$ & $61.14^{\mathrm{ab}}$ & $61.47^{\mathrm{ab}}$ & $65.59^{\mathrm{a}}$ & $59.90^{\mathrm{ab}}$ & 0.70 \\
\hline $\mathrm{EE}, \%$ & $36.24^{\mathrm{ab}}$ & $35.16^{\mathrm{ab}}$ & $39.16^{a}$ & $36.68^{\mathrm{ab}}$ & $36.01^{\mathrm{ab}}$ & $32.04^{b}$ & $37.08^{\mathrm{ab}}$ & 0.67 \\
\hline Ash, \% & $2.66^{\mathrm{ab}}$ & $1.92^{c}$ & $1.94^{c}$ & $2.18^{\mathrm{bc}}$ & $2.52^{\mathrm{ab}}$ & $2.37^{\mathrm{bc}}$ & $3.02^{\mathrm{a}}$ & 0.09 \\
\hline
\end{tabular}

$\mathrm{a}, \mathrm{b}$ and $\mathrm{c}$ : Means in the same row have different superscripts are differ significantly at $P<0.05$

SEM: Standard error of the mean

reported that the dressing percentage for rabbits fed diets contained 25 and $50 \%$ fungal treated sugar beet pulp (TSBP) (75.15 and 73.96) were not different compared with control (72.14), but it were significantly $(P<0.05)$ higher than $(69.15$ and $64.05 \%)$ for rabbits fed 25 and $50 \%$ untreated sugar beet pulp (USBP). These differences in dressing percentages may be due to the nature and type of materials of roughages (wheat straw, sugar beet pulp and corn stalks) which treated with fungi or to the differences of component diets, also to the experimental conditions of each experiment. These results are disagreement with Thayalim and Samanasinghe (2002) who found that addition effective microorganism (EM) to rabbit diets increased dressing percentages.

Concerning the effects of fungal treatment and replacing levels of corn stalks on carcass cuts weight are shown in Table 2, it was cleared that treated corn stalks with fungi improved Fore part, Middle part and Hind part by about $8.05,6.74$ and $8.95 \%$ for treated corn stalks with fungi than that of without fungi, respectively, however, no significant differences between treatments with or without treatment were detected in this respect. Replacing levels of clover hay by treated corn stalks at 33, 66 and 100\% showed that 33, 66 and 100\% levels improved Middle part of carcass cut weight significantly than that of control diet, however, no significant differences were detected with Fore part, Hind part or head + neck with different levels of supplement than that of control diet. These results cleared that increasing levels of treated corn stalks form 33, 66 to $100 \%$ were improved $(P<0.05)$ the excellent carcass cuts weight (Middle part) than that of control diet.

Concerning the effects of fungal treatment and replacing levels of corn stalks on edible offals (giblets) are shown in Table 2, it was cleared that treated corn stalks with fungi increased liver weight significantly than that of without treatment, however, no significant differences were observed in the rest of giblets. Replacing levels of clover hay by treated corn stalks at 33, 66 and 100\% showed that 66 and 100\% levels significantly increased liver and total giblets than that of control diet; no significant differences were detected in the rest of giblets, at different levels of supplement. These results are agreement with El-Badawi et al. (2007), they reported that the edible giblets percentage, especially liver, kidneys and heart were higher for rabbits fed TSBP diets, especially at $50 \%$ compared with rabbits fed $25 \%$ USBP and control diets.

The interaction between treatments and levels are shown in Table 3. The results indicated that there were no significant differences in values of EBW, CW1, CW2, dressing DP1, DP2, DP3 and carcass cuts weight between without or with fungi treatment. However, treated fungi at 66 or $100 \%$ showed significant increase in liver and total edibles offals (giblets) than that of control diet.

\section{Meat composition}

Table 4 showed that the effect of treatments and levels on meat composition evident that ash content of rabbits meat were significantly higher with treated corn stalks with fungi than that of without fungi. Ether extract (EE) content of meat was nearly similar and somewhat lower by about $4 \%$ with than without fungal treatment with non-significant differences detected between treatments. However, dry matter (DM) and crude protein (CP) contents of meat showed non-significant differences detected between treatments. Effect of replacing levels of treated corn stalks on chemical composition of rabbits meat showed that DM content of meat increased by $11.5,13.8$ and $12.8 \%$ with 33, 66 and $100 \%$ levels, respectively with non-significant differences observed between different levels and control treatments, may be due to the large variations within groups and the relatively small numbers of observations. Also, CP and EE contents of meat showed non-significant differences between treatments. However, ash content of meat showed significant differences between control and 100\% than that of 33 and $66 \%$ levels of corn stalks.

The effect of interactions between treatments and levels of corn stalks on chemical composition of rabbits meat (Table 5), cleared that CP content significantly increased with $66 \%$ with fungi than that the same level without fungi, with the contrast with EE which significantly decreased with fungi than that of the sane level 
(66\% without fungi). Moreover, ash content showed significantly higher with $100 \%$ with fungi than 33 and $66 \%$ without fungi treatment. Non-significant differences detected between either with or without fungi on DM of rabbits meat. Cheeke (1986) reported that rabbit meat is high in protein and low in fat. Matusevivius et al. (2006) found that adding probiotic to rabbit rations did not have any influence on dry matter and ash.

In this connection, Zaza (2005) found that incorporation of either treated or non- treated apple pomace to rabbit diets led to significant reduction in the fat content of rabbits meat and insignificant differences $(p>0.05)$ were found among all treatments in crude protein content. El-Badawi et al. (2007) reported that chemical composition of lean meal showed higher content of DM, but less EE content for rabbits fed untreated SBP diets compared with control group. Rabbits fed treated SBP recorded higher ash content compared with those fed control and 25\% USBP diets. CP content was not different between all groups.

\section{Conclusion}

From the previous results could be concluded that treated corn stalks with or without fungi could be successfully used to improve carcass cuts weight (Middle part) and total giblets with 33 to $100 \%$ than control diet. Treated corn stalks with fungi at $66 \%$ increased $\mathrm{CP}$ content, while decreased EE content of rabbits meat compared with without fungi. Ash content increased with 100\% treated than 33 or $66 \%$ without fungi treatment. It worthy to note that treated corn stalks with fungi could be used without any adverse effects and enhance carcass characteristics and chemical composition of rabbits meat.

\section{Abbreviations \\ AOAC: Association of Official Analytical Chemists; CP: Crude protein; $\mathrm{CW}_{1}$ : Carcass weight; $\mathrm{CW}_{2}$ : Carcass weight + total edible offals; DM: Dry matter; $\mathrm{DP}_{1}$ : Dressing percentage $=\mathrm{CW}_{1} / \mathrm{SW}_{i} \mathrm{DP}_{2}$ : Dressing percentage $=\mathrm{CW}_{2} / \mathrm{EBW}$; $\mathrm{DP}_{3}$ : Dressing percentage $=\mathrm{CW}_{2}+$ total edible offals / EBW; EBW: Empty body weight; EE: Ether extract; hr: Hour; MALR: Ministry of Agriculture and Land Reclamation; ml: Milliliter; NRC: National Research Council; SBP: Sugar beet pulp; SEM: Standard error of the mean; SPSS: Statistical Package for the Social Siemens; SW: Slaughter weight; T: Trichoderma; TSBP: Treated sugar beet pulp; USBP: Untreated sugar beet pulp}

\section{Acknowledgements}

Not applicable.

\section{Funding}

This work was funded by the National Research Centre.

\section{Availability of data and materials}

The authors declare that all data and the materials are available.

\section{Authors' contributions}

RIE designed this work and wrote the manuscript, AAAM performed the farm trials and laboratory analysis, AAA participated in farm trials and wrote the manuscript, AAE designed this work. All authors read and approved the final manuscript.
Ethics approval and consent to participate

Did not done the ethics process for this work. All authors declare consent to participate.

\section{Consent for publication}

All authors declare that this manuscript is consent for publication.

\section{Competing interests}

The authors declare that they have no competing interests.

\section{Publisher's Note}

Springer Nature remains neutral with regard to jurisdictional claims in published maps and institutional affiliations.

Received: 4 February 2019 Accepted: 3 April 2019

Published online: 10 May 2019

\section{References}

Abd El-Hakim AS, Shakweer IME, Azoz AA (2006) Effect of using different levels of biologically treated rice straw in growing rabbits diets on growth performance, nutrients digestibility and some physiologies parameters. Egypt J Rabbit Sci 16(2):191-209

Abedo AA (2011) Prospects of recycling field crop residues in animal feeding strategy. Animal Production Department, National Research Center, Giza, pp 7-8

Agricultural Economic and Statistics Institute (2011) Ministry of Agriculture, Agri., Economic, part 1. Pub., Agri. Res. Center, Egypt

Ahmed FG (1998) Improvement the nutritive value of some roughages used for rabbits feeding. M.Sc. Thesis, Fac Agric, Ain Shams Univ, Egypt

AOAC (2000) Association of official analytical chemists, 17th edn. Assoc. of Anal Chem, Arlington

Cheeke PR (1986) Potentials of rabbit production in tropical and subtropical agricultural systems. J Anim Sci 63:1581-1586

Cheeke PR (1987) Rabbit feeding and nutrition. Academic Press, INC, Orlando, p 367

Deraz TAA, Ismail H (2001) Cotton stalks treated with white-rot fungi for feeding sheep. Egypt J Nutr Feed 4(Special Issue):423-434

Duncan DB (1955) Multiple range and multiple F test. Biometrics 11:1

El-Ayek MY, El-Ayouty El-Sayd A, El-Shahat AA, El-Kady RI, Morad AAA (2014) Effect of some biological treatments for corn stalks on productive performance of New Zealand rabbits. Egypt J Nutr Feed 17(1):75-88

El-Badawi AY, Hassan AA, Abedo AA (2007) Growth performance of New-Zealand white rabbits fed diets containing different levels of untreated or fungal treated sugar beet pulp. In: The 58 ${ }^{\text {th }}$ EAAP meeting, August 26-29, 2007. Dublin, Ireland

Fadel M, Amara H, Murad HA, El-Shinawy HK (1992) Production of fungal protein from wheat straw by Pencillium funculosium. Egypt J Food Sci 20:1

Hernandez P, Pla M, Oliver MA, Blasco A (2000) Relationship between meat quality measurements in rabbits fed with three diets of different fat type and content. Meat Sci 55:379-384

MALR (2008) Ministry of agriculture and land reclamation part 1. Published by Agric Res Center, Ministry of Agriculture, Egypt

Matusevivius P, Asmenskaite L, Zilinskiene A, Gugolek A, Manfred O, Hartman A (2006) Effect of probiotic bioplus $2 \mathrm{~B}^{\circledR}$ on performance growing rabbit. Veterinarija IR Zootechinika 36(58):54-59

Morad AAA (2005) Microbial and physiological studies for improving the nutritional value of untraditional animal feeds. M.Sc. Thesis Faculty of Agric, Al-Azhar, University, Egypt

Nofal RY, Toth S, Virag GY (1995) Carcass traits of purebred and crossbred rabbits. World Rabbit Sci 3(4):167-170

NRC (1977) National Research Council. Nutrient requirements of rabbits. National Academy of Sciences, Washington, DC

Rangnekar DV, Badve VC, Kharat ST, Sobole BN, Joshi AL (1982) Effect of high pressure steam treatment on chemical composition and in vitro digestibility of roughages. Anim Feed Sci Technol 7:61-70

Rissanen H, Kossila V, Kommeri M, Lampila M (1981) Ammonia treated straw in the feeding of dairy cows and growing cattle. Agric Environ 6:267-271

SPSS (1997) Statistical package for the social siemens, release 6. SPSS Inc., Chicago 
Thayalim S, Samanasinghe K (2002) Influence of EM on the performance of the domestic rabbit (oryctogu cuniculus). In: 7th international conference on kyusei nature fanning, New Zealand, pp 7-8

Zaza GHM (2005) Effect of incorporation of biologically treated sugar beet pulp as non-conventional feedstuffs in the diets of growing rabbits. In: The $4^{\text {th }}$ inter. conference on Rabbits production in hot climates, Sharm El-Sheikh, Egypt

Submit your manuscript to a SpringerOpen ${ }^{\mathcal{O}}$ journal and benefit from:

- Convenient online submission

- Rigorous peer review

- Open access: articles freely available online

High visibility within the field

- Retaining the copyright to your article

Submit your next manuscript at $\boldsymbol{\wedge}$ springeropen.com 